\title{
Tyrosine-Protein Kinase Receptor Tie-1
}

National Cancer Institute

\section{Source}

National Cancer Institute. Tyrosine-Protein Kinase Receptor Tie-1. NCI Thesaurus. Code C30100.

Tyrosine-protein kinase receptor Tie-1 (1138 aa, $125 \mathrm{kDa}$ ) is encoded by the human

TIE1 gene. This protein plays a role in tyrosine phosphorylation and angiogenesis. 